\title{
ANALISIS PENGARUH FREE CASH FLOW DAN PROFITABILITAS TERHADAP LEVERAGE PERUSAHAAN DENGAN INVESMENT OPPORTUNITY SET SEBAGAI VARIABEL MODERATING PADA SEKTOR TRADE, SERVICES \&INVESTMENT YANG TERDAFTAR PADA BEI
}

\author{
Prisilia Agustin, Aminar Sutra Dewi \\ Sekolah Tinggi Ilmu Ekonomi KBP \\ prisilia.agustin09@gmail.com
}

\begin{abstract}
ABSTRACK
The decline in the purchasing power of the public, as seen from the decline in the growth of Trade, Services and Investment sector in the retail sector subsector Retail sub-sector condition has been 2.5 years underperformance. This study aims to test whether the influence of Investment Opportunity Set (IOS) free cash flow and profitability to leverage. Population in this research is Trade Company, Services \& Investment, retail subsector, which is listed on BEI. period 2014-2016, ie as many as 23 Companies. Using the technique of porposive sampling, the sample in this study were 15 companies. Data analysis technique that is rergesion analysis by using moderating variable. From the test results, showed that the Free cash flow has a significant effect on leverage, which is indicated from the significance value $>0.05$ is 0.018 . Profitability has a significant effect on firm leverage which is shown from significance value>0.05 ie 0.000. IOS does not affect the relationship between free cash flow and leverage, as indicated by the significance value of IOS interaction with free cash flow <0.05 is 0.053. And IOS Set affects the relationship between Profitability with leverage shown from the significance value of IOS interaction with Profitability>0.05 is 0.044
\end{abstract}

Keywords: free cash flow, profitability, IOS, leverage

\section{PENDAHULUAN}

Leverage pada halnya sangat diperlukan sebagai alat dalam mengukur seberapa besarnya penggunaan hutang pada suatu perusahaan. Leverage dapat digunakan sebagai acuan bagi perusahaan maupun investor dalam besarnya penggunaan hutang dibandingkan ekuitas. Selain itu dalam mengukur besarnya suatu aktiva yang akan dibiayai oleh hutang yaitu menggunakan leverage. Kreditor membiayai aktiva dalam bentuk penggunaan hutang, sementara hutang yang digunakan bukan berasal dari investor maupun pemegang saham (Sudarmadji dkk, 2007).Dalam memenuhi kebutuhan operasional suatu perusahaan, sebagian sumber dana berasal dari hutang, dengan demikian perusahaan harus memenuhi kewajibannya sesuai dengan kesepakatan yang telah 
disepakati dengan pihak yang bersangkutan. Dalam melunasi hutang, maka setiap perusahaan harus melihat tingakat leverage suatu perusahaan.

Pecking Order Theory Myers dan Majluf (1984) dalam (Hardiningsih \& Oktaviani, 2012) menjelaskan suatu perusahaan menentukan hierarki sumber dana yang paling disukai. Teori ini mendasarkan pada adanya suatu informasi asimetrik, yaitu suatu situasi dimana pihak manajemen mempunyai suatu informasi yang lebih banyak tentang perusahaan daripada setiap pemilik modal. Informasi asimetrik ini akan mempengaruhi pilihan diantara penggunaan dana internal ataupun dana eksternal serta diantara pilihan penambahan hutang baru atau penerbitan ekuitas yang baru. Menurut Sunder dan Myers (1992) dalam (Indahningrum \& Handayani, 2009), dalam bentuk yang paling sederhana, pecking order model dalam pendanaan perusahaan menjelaskan bahwa saat situasi arus kas internal tidak sanggup mencukupi dalam mendanai investasi real dan dividen, oleh karena itu perusahaan akan melakukan penerbitan hutang.

Pada tahun 2017 terjadinya penurunan daya beli masyarakat, terlihat dari anjloknya pertumbuhan sektor Trade, Services dan Investment yaitu pada subsektor perusahaan ritel. Pada subsektor ritel pertumbuhannya minus, kelesuan penjualan ritel sudah terjadi 2.5 tahun yang lalu, kondisi subsektor industri ritel pada saat ini telah 2,5 tahun underperformance, yang membuat situasi peritel di Indonesia berada dalam kondisi yang terpuruk. Adapun dampak yang akan terjadi dalam perusahaan ritel (retail trade) jika daya beli turun secara terus menerus maka industri ritel akan mengalami penurunan tingkat penjualan, yang mana data yang tercatat pada BAPPENAS menunjukan bahwa pertumbuhan penjualan ritel riil dari 16,3 persen pada Juni 2016, anjlok menjadi 6,7 persen di Juni 2017. Semantara hutang yang dipergunakan dalam kegiatan operaional perusahaan terus bertambah. Dengan ini kesulitan perusahaan dalam melunasi hutang-hutangnya akan terjadi adapun dampak lainnya maka minat investor akan berkurang (Liputan6, 2017).

Leverage menurut Brigham dan Houston pada bukunya yang berjudul Dasar-Dasar Manajemen Keuangan (2010;140) yaitu sampai sejauh apa perusahaan dalam menggunakan pendanaannya melalui hutang. Menurut (Gunawan dkk, 2015) dalam membiayai aset suatu perusahaan dalam rangka menjalankanaktivitas operasional perusahaan dengan menggunakan hutang merupakan pengertian dari leverage. Menurut (Dewi, 2012) Leverage menurut rasio antara total kewajiban dengan total aset. Semakin tinggi tingkat hutang pada suatu perusahaan maka akan semakin tinggi juga resiko yang akan dihadapi oleh pemilik, dimana pemilik akan meminta tingkat keuntungan yang semakin semakin tinggi guna perusahaan tersebut tidak terancam dilikuidasi.

Free cash flow adalah arus kas akutual yang mana didistribusikan kepada investor ketika perusahaan telah melakukan seluruh investasi dan modal yang diperlukan guna menjaga keberlangsungan suatu operasional perusahaan. Selain kas yang diperoleh dari suatu aktivitas operasi yang dikurangi dengan pengeluaran modal yang diperlukan guna mempertahankan tingkat pada operasi sekarang, sehingga peneliti wajib melakukan identifikasi terhadap pengeluaran modal dalam arus kas investasi sehubungan upaya mempertahankan kegiatan operasi yang berlangsung termasuk pada free cash flow (Suastawan, 2014). 
Profitabilitas yakni suatu kemampuan perusahaan agar menghasilkan laba selama periode terntentu. Profitabilitas memperlihatkan perbandingan laba dengan aktiva ataupun modal yang menciptakan laba. Profitabilitas menggambarkan kemapuan perusahaan dalam mendapatkan laba melalui seluruh kemampuan, serta sumber yang tersedia seperti halnya kas, modal, kegiatan penjualan, jumlah karyawan serta jumlah cabang, dan yang lainnya. Selain bahwa profitabilitas yakni kemampuan perusahaan dalam memperoleh laba pada masa periode tertentu, dimana dapat dihitung melalui penjualan/total aktiva/modal sendiri (Novelma, 2014)

Invesment Opportunity Set yaitu bagian-bagian dari nilai perusahaan serta ialah hasil dari pilihan-pilihan dalam melakukan keputusan investasi dimasa mendatang, selain itu Invesment Opportunity Set ialah kesempatan berupa kombinasi aktiva yang dimiliki dan pilihan investasi dimasa mendatang. Semakin tinggi kesempatan investasi, maka dividen yang akan dibagikan jadi lebih sedikit, dikarenakan lebih baik jika dana tersebut ditanamkan pada investasi yang menghasilkan tingkat NPV positif (Natalia, 2013).

Beberapa penelitian terdahulu yang telah meneliti tentang leverage dengan menggunakan varibel moderating, yakni seperti pada penelitian yang dilakukan (Kennedy, 2009) yang meneliti tentang Pengaruh Dividen, Aliran Kas Bebas, Ukuran Perusahaan, Profitabilitas dan Risiko Terhadap Leverage Perusahaan Dengan Set Kesempatan Investasi (IOS) Sebagai Variabel Moderating. Temuan mereka menunjukan bahwa IOS tidak mempengaruhi hubungan antara aliran kas bebas dengan leverage perusahaan dan IOS mempengaruhi memperkuat hubungan antara profitabilitas dengan leverage perusahaan. Namun dalam penelitian (Masruroh dkk, 2011) bahwa hasil moderated regression analysis menyimpulkan bahwa arus kas bebas berpengaruh terhadap tingkat leverage perusahaan. Dari dua penelitian yang dilakukan oleh (Kennedy, 2009) dan (Masruroh dkk, 2011) yang menemukan hasil yang berbeda mungkin ada faktor lain yang menyebabkan penemuan dari hasil penelitian kedua peneliti tersebut berbeda.

Berdasarkan latar belakang yang tertera maka peneliti tertarik untuk meneliti kembali dengan judul "Pengaruh Free Cash Flow dan Profitabilitas Terhadap Leverage Perusahaan Dengan Invesment Opportunity Set Sebagai Variabel Moderating

Keberadaan free cash flow bagi perusahaan berpotensi untuk menimbulkan sebuah konflik keagenan diantara pemegang saham serta manajer.Pada halnya pemegang saham lebih menginginkan agar sisa dana dibagikan kepada mereka berupa dividen. Sedangkan dalam menginvestasikan dana yang telah tersedia manajer lebih suka menginvestasikannya pada proyek yang lebih menguntungkan dengan harapan bisa meningkatkan insentif bagi para manajer dimasa mendatang. Jensen (1986) dalam (Fitriyah \& Hidayat, 2006) berpendapat bahwa salah satu solusi untuk mengurangi biaya keagenan yang timbul akibat konflik keagenan ini adalah dengan hutang. Dengan adanya hutang, manajer termotivasi dalam bekerja.Peneliti yang lain mengemukakan bahwa free cash flow sebagai deskripsi dari kas yang tersedia setelah memenuhi segala kewajiban atau tanggung jawabnya, yaitu keperluan pembayaran untuk menjalankan suatu aktivitas operasi. 
Pendapat lainnya yaitu free cash flow menerangkan tentang kas yang tersedia setelah dipotong biaya operasi, baik untuk menambah modal kerja dan operating assets maintenance (Suastawan, 2014). Pada penelitian yang dilakukan oleh (Indahningrum \& Handayani, 2009) menunjukan bahwa free cash flow berpengaruh terhadap kebijakan hutang (leverage) perusahaan. Penelitian free cash flow terhadap hutang juga dilakukan oleh (Nurwahyudi, 2004) bahwa penelitian yang dilakukannya menunjukan free cash flow berpengaruh terhadap hutang (leverage). Maka dapat disimpulkan bahwa hipotesis pertama $\left(\mathrm{H}_{1}\right)$ adalah diduga free cash flow berpengaruh positif dan signifikan terhadap leverage perusahaan.

Profitabilitas merefleksikan earnings untuk pendanaan investasi. menyarankan manajer agar menggunakan pecking order dalam keputusan pendanaan. Pecking Order ialah urutan dalam penggunanan dana untuk investasi yakni laba ditahan sebagai pilihan yang pertama, selanjutnya akan diikuti oleh hutang dan ekuitas. Apabila benar, implikasinya yakni adanya suatu hubungan yang negatif diantara profitabilitas dengan debt ratio. Pihak insider tidak ingin berbagi dalam keuntungan bersama kreditur sehingga adanya kecenderungan terhadap debt ratio perusahaan yang lebih kecil (Indahningrum \& Handayani, 2009).Berdasarkan agency theory seharusnya perusahaan yang mempunyai nilai profitabilitas yang tinggi memanfaatkan hutang untuk mengurangi penyalahgunaan pemakaian dana oleh manajer yang mana tidak memperhatikan keperluan pemegang saham. Perusahaan yang menghasilkan laba yang tinggi tentunya akan membuat setiap pemegang saham mengajukan usulan dalam pembagian laba tersebut berupa dividen. Profit yang semakin besar akan merasa bahwa mereka mempunyai kesempatan yang cukup besar untuk bisa lebih mengembangkan usahanya. Untuk mecukupi kebutuhan investasi yang besar tersebut memerlukan dana tambahan yang bersumber dari hutang. Pada penelitian yang dikemukan oleh (Suastawan, 2014) menunujukan bahwa terdapat adanya pengaruh yang signifikan antara variabel profitabilitas pada kebijakan utang (leverage) perusahaan. Penelitian yang dijuga dilakukan (Indahningrum \& Handayani, 2009) menunjukan bahwa profitabilitas berpengaruh terhadap kebijakan hutang (Leverage). Penelitian yang berkaitan dengan pengaruh profitabilitas terhadap leverege juga dilakukan oleh (Nabela, 2012) dalam penelitiannya menunjukan bahwa profitabilitas berpengaruh terhadap kebijakan hutang. Maka dapat disimpulkan bahwa hipotesis kedua $\left(\mathrm{H}_{2}\right)$ adalah diduga profitabilitas berpengaruh negatif dan signifikan terhadap leverage perusahaan.

Jensen (1986) dalam (Kennedy, 2009) menyatakan hutang dapat mengurangi keleluasaan manajemen menggunakan free cash flow bagi kegiatan dimana bersifat non maximize value. Dengan adanya utang menyebabkan manajer harus membayar pokok dan bunga pinjaman secara periodik dan harus mematuhi ketentuan-ketentuan dalam perjanjian hutang. Jensen juga menyatakan kecenderungan manajer melakukan pemborosan pada aliran kas bebas lebih besar terjadi pada perusahaan yang investment opportunity set rendah. Maka dari itu, pengawasan lebih dibutuhkan terhadap perusahaan yang terdapat tingkat free cash flow tinggi dengan investment opportunity set rendah. Tetapi menurut Myres (1997) dalam (Masruroh dkk, 2007) perusahaan dengan investment opportunity 
set (IOS) tinggi menunjukkan bahwa nilai perusahaan lebih banyak ditentukan oleh intangible asset dari pada asset riilnya. Kriteria perusahaan ini biasanya akan mempunyai keterbatasan dalam mendapatkan hutang, karena mereka kurang memiliki asset riil yang dapat digunakan sebagai jaminan utang. Selain itu, investment opportunity set (IOS) tinggi mencerminkan tinggi risiko sebagaimana akan ditanggung oleh setiap lender sehingga menyebabkan cost of debt bagi perusahaan serta kesanggupan perusahaan untuk mengakses ke lender. Pada Penelitian yang dikemukakan oleh (Kennedy, 2009) mengenai pengaruh Invesment Opportunity Set (IOS) terhadap hubungan antara free cash flow dengan leverage perusahaan dalam penelitiannya menunjukan bahwa IOS tidak mempengaruhi hubungan antara free cash flow dengan leverage perusahaan. Sedangkan penelitian yang dilakukan oleh (Masruroh dkk, 2011) menunjukan bahwa Invesment Opportunity Set (IOS) tidak mempengaruhi hubungan antara Free cash flow dengan leverage. Maka dapat disimpulkan bahwa hipotesis ketiga $\left(\mathrm{H}_{3}\right)$ adalah diduga Invesment Opportunity Set (IOS) tidak berpengaruh terhadap hubungan antara Free cash flow dengan leverage perusahaan.

Menurut Amiruddin (2003) dalam (Kennedy, 2009) perusahaan yang memiliki peluang pertumbuhan tinggi, rasio utang berkorelasi secara negatif dengan nilai perusahaan, karena para manajer selalu memiliki keuntungan informasi dibandingkan dengan pihak luar. Bagi pemerhati pasar, rasio utang dapat dipandang sebagai sinyal, secara potensial ada korelasi negatif antara utang dan nilai perusahaan ketika perusahaan mempunyai peluang pertumbuhan yang prospektif. Anggria (2006) dalam (Kennedy, 2009) menyatakan profitabilitas secara simultan berpengaruh signifikan terhadap leverage perusahaan. Dalam hal ini memperlihatkan bahwa semakin tingginya porsi dana yang tersedia dalam membiayai operasional perusahaan dan Invesment Opportunity Set yang berasal dari retained earning (laba) maka tingkat leverage perusahaan jugaakan semakin tinggi. Pada Penelitian yang dilakukan oleh (Kennedy, 2009) mengenai pengaruh Invesment Opportunity Set (IOS) terhadap hubungan antara profitabilitas dengan leverage perusahaan, dalam penelitiannya menunjukan bahwa Invesment Opportunity Set (IOS) mempengaruhi memperkuat hubungan antara profitabilitas dengan leverage perusahaan.Sedang penelitian yang dilakukan oleh (Rahayu \& Wirawan Yasa, 2018) menunjukan hasil yang berbeda bahwa hasil dari penelitiannya menunjukan Investment Opportunity Set tidak mampu memperkuat pengaruh negatif profitabilitas terhadap kebijakan hutang Maka dapat disimpulkan bahwa hipotesis keempat $\left(\mathrm{H}_{4}\right)$ adalah diduga Invesment Opportunity Set (IOS) berpengaruh signifikan terhadap hubungan antara profitabilitas dengan leverage perusahaan.

\section{METODE PENELITIAN}

Jenis penelitian pada penelitian ini ialah kuantitatif. Bahwa penelitian kuantitatif yakni metode penelitian berdasarkan pada suatu filsafat positivisme, dimana digunakan meneliti pada populasi ataupun sampel tertentu, pengumpulan data yang menggunakan instrumen penelitian, serta analisis data yang bersifat kuantitatif atau statistik, yang mana bertujuan untuk menguji hipotesis yang sudah ditetapkan (Sugiyono, 2015). Objek pada peneltian ini adalah sektor Trade, 
Services dan Investment yang terdaftar di Bursa Efek Indonesia. Populasi pada penelitian ini adalah semua Trade, Services dan Investment yang terdaftar di Bursa Efek Indonesia yang mana berjumlah 98 perusahaan pada tahun 2014-2016. teknik pengambilan sampel adalah Sampling Purposive. Dari teknik tersebut sampel penelitian yang memenuhi keseluruhan kriterianya sebanyak 15 perusahaan ritel .Jenis data dalam penelitian ini data kuantitatif yang bersumber dari data sekunder berupa laporan keuangan dari perusahaan sampel yang dipublikasikan pada website Bursa Efek Indonesia www.idx.co.id

Tabel 1

Defenisi Operasional Variabel

\begin{tabular}{|c|c|c|c|c|}
\hline No & Variabel & Defenisi & Pengukuran & Sumber \\
\hline 1 & $\begin{array}{l}\text { Debt Equity } \\
\text { Ratio (DER) }\end{array}$ & $\begin{array}{l}\text { Perbandingan } \\
\text { antara total hutang } \\
\text { dengan total aset } \\
\text { (ekuitas). }\end{array}$ & $\begin{array}{l}\text { Debt Equity Ratio }(\mathrm{DER})= \\
\frac{\text { Total Hutang }}{\text { total aset }}\end{array}$ & $\begin{array}{c}\text { (Brigham \& Houston, } \\
2010)\end{array}$ \\
\hline 2 & $\begin{array}{l}\text { Free Cash } \\
\text { Flow }\end{array}$ & $\begin{array}{l}\text { Mengurangkan arus } \\
\text { kas operasi dengan } \\
\text { pengeluaran modal } \\
\text { bersih dan modal } \\
\text { kerja bersih }\end{array}$ & $\begin{array}{l}\text { FCF }=\text { Arus kas operasi - } \\
\text { Investasi dalam modal } \\
\text { operasi }\end{array}$ & $\begin{array}{c}\text { (Brigham \& Houston, } \\
2010)\end{array}$ \\
\hline 3 & $\begin{array}{l}\text { Return On } \\
\text { Investment } \\
\text { (ROI) }\end{array}$ & $\begin{array}{l}\text { Perbandingan } \\
\text { antara laba setelah } \\
\text { pajak dengan total } \\
\text { aset }\end{array}$ & $\begin{array}{l}\text { ROI }= \\
\qquad \frac{\text { Laba Setelah pajak }}{\text { total aset }}\end{array}$ & $\begin{array}{c}\text { (Brigham \& Houston, } \\
2010)\end{array}$ \\
\hline 4 & $\begin{array}{l}\text { Market to } \\
\text { book value of } \\
\text { equity } \\
\text { (MVEBVE) }\end{array}$ & $\begin{array}{l}\text { Pervandingan } \\
\text { antara lembar } \\
\text { saham beredar yang } \\
\text { dikalikan harga } \\
\text { saham penutup } \\
\text { dengan total ekuitas }\end{array}$ & $\begin{array}{l}\text { MVEBVE }= \\
\text { Lembar Saham Beredar } \mathrm{x} \\
\frac{\text { harga saham penutupan }}{\text { total ekuitas }}\end{array}$ & (Masruroh dkk, 2011) \\
\hline
\end{tabular}

\section{Teknik Analisis Data}

\section{Analisis Statistik Deskriptif}

Statistik deskriptif yaitu statistik yang berfungsi guna mendeskripsikan ataupun memberikan gambaran pada objek yang diteliti berdasarkan data sampel ataupun populasi yang sebagaimana mestinya, tanpa dilakukannya analisis serta membuat kesimpulannya yang berlaku secara umum . Pada statistik deskriptif, mengemukakan cara-cara bentuk penyajian data dalam bentuk tabel biasa ataupun distribusi frekuensi, dengan grafik, pictogram serta diagram lingkaran(Sugiyono, 2015).

\section{Uji Asumsi Klasik}

Ada tiga asumsi yang terpenting sebagai syarat penggunaan metode. Asumsi klasik tersebut adalah asumsi normalitas, Multikolinearitas, dan heterokedastisitas.

\section{Uji Normalitas}

Uji Normalitas dilakukan bertujuan menguji apakah sampel pada penelitian ini merupakan jenis data yang terdistribusi secara normal (Rahmawati, 2009). Apabila hasil uji normalitas dengan uji Kolmogorov-Smirnov, diketahui 
bahwa Alpha $(>0,05)$, sehingga dapat dikatakan bahwa data terdistribusi normal serta asumsi normalitas telah terpenuhi dan sebaliknya apabila aplha $(<0,05)$ maka data tidak terdistribusi secara normal.

\section{Uji Multikolinearitas}

Uji multikolinieritas bertujuan untuk apakah model regresi ditemukan adanya korelasi antar variabel bebas atau (independent). Untuk melihat adanya atau tidak adanya multikolinieritas pada model regresi dapat dilihat pada nilai tolerance dan variance inflation factor (VIF). Dari kedua ukuran atau nilai tersebut memperlihtakan setiap variabel bebas yang manakah yang dijelaskan oleh variabel bebas lainnya. Dalam pengertian yang sederhana setiap variabel independent menjadi variabel independent (terikat) serta diregres terhadap variabel bebas lainnya. Tolerance mengukur suatu variabilitas variabel independent yang terpilih, yang mana tidak dijelaskan dari variabel independent lainnya. Nilai tingkay cut-off pada umum dipakai guna menunjukkan adanya gejala multikolinieritas yakni nilai tolerance $<0,10$ ataupun sama dengan nilai VIF > 10 (Ghozali, 2012).

\section{Uji heteroskidastisitas}

Heteroskidastisitas dilakukan untuk mengindikasikan suatu varians konstan yang memperoleh model estimator tidak bias (Dhania, 2010). Uji heteroskidastisitas dilakukan untuk menguji apakah dalam suatu model regresi terjadinya ketidaksamaan variance dari residual satu pengamatan ke pengamatan yang lainnya. Model regresi menunjukan yang baik yaitu yang tidak terjadinya heteroskidastisitas. Untuk melihat adanya atapun tidak adanya heteroskedastisitas bisa dilakukan dengan uji Glejser. Dalam uji ini apabila signifikasinya diatas tingkat kepercayaan 5\% $(0,05)$. Jadi disimpulkan ,model regresi tidak mengandung adanya heteroskedastisitas (Ghozali, 2012)

\section{Analisis Regresi dengan Variabel Moderating}

Analisis regresi linear dengan menggunakan variabel moderating ini, digunakan untuk melihat suatu hubungan antara sebuah variabel dependen (tidak bebas) dengan dua atau lebih variabel independen (bebas) pada tahap I (satu). Sedangkan pada tahap II (dua), analisis linear dengan variabel moderating digunakan dalam melihat pengaruh moderasi dalam mempengaruhi hubungan antara variabel independen terhadap variabel dependen

Adapun persamaan dalam penelitian ini adalah :

1. Analisis Regresi Tahap I

$Y=\alpha+\beta_{1} X_{1}+\beta_{2} X_{2}+e$

2. Analisis Regresi Tahap II

$Y=\alpha+\beta_{1} X_{1}+\beta_{2} X_{2}+\beta_{1} X_{1} * Z+\beta_{2} X_{2} * Z$

Dimana $: Y=$ Leverage

$\mathrm{A}=$ Bilangan Konstanta

$\beta_{1}=$ Koefisen Regresi Free cash flow

$\beta_{1}=$ Koefisen Regresi Profitabilitas

$\mathrm{X}_{1}=$ Free cash flow

$\mathrm{X}_{2}=$ Profitabilitas

$\mathrm{Z}=$ Invesment Opportunity Set (IOS) 
4. Uji Hipotesis

- Uji F (Simultan) merupakan pengujian hubungan regresi secara simultan dari variabel-variabel terikat (dependent) yang mana bertujuan apakah secara bersama-sama semua variabel bebas (independent) memiliki pengaruh yang signifikan pada variabel dependent

- Uji T, uji ini digunakan untuk melihat pengaruh variabel independen terhadap variabel dependen sacara parsial

- Koefisien determinasi digunakan untuk mengukur sejauh mana kemampuan variabel bebas $(\mathrm{X})$ dalam menerangkan variabel terikat $(\mathrm{Y})$. Nilai Adjusted $\mathrm{R}$ Square $\left(\mathrm{R}^{2}\right)$ yang berada diantara nilai nol sampai dengan nilai satu.

\section{HASIL DAN PEMBAHASAN}

Analisis statistik deskriptif

Berdasarkan analisis deskripsi variabel yang telah dilakukan, maka ditampilkan karakteristik yang digunakan dalam penelitian meliputi : Jumlah sampel $(\mathrm{N})$, nilai terendah (minimum), nilai tertinggi (maxsimum), nilai rata-rata

Tabel 2

Descriptive Statistics

\begin{tabular}{lcrrrr}
\hline \hline & N & Minimum & Maximum & Mean & Std. Deviation \\
\hline \hline Leverage (Y) & 45 & .01 & 9.55 & .7584 & 1.47757 \\
Free Cash Flow (X1) & 45 & -2.08 & 6.58 & 9.0242 & 1.61652 \\
Profitabilitas (X2) & 45 & -.68 & .46 & .0400 & .16295 \\
Investment Opportunity Set (Z) & 45 & -.60 & 243.25 & 9.0685 & 36.51224 \\
Valid N (listwise) & 45 & & & & \\
\hline \hline
\end{tabular}

sampel (mean) dan standar deviasi pada setiap variabel.

Pada tabel diatas menunjukan bahwa jumlah data yang digunakan pada penelitian ini adalah sebanyak 45 sampel, Nilai terendah dan nilai tertinggi Leverage, Free Cash Flow, Profitabilitas dan Investment Opportunity Set dapat dilihat pada tabel diatas. Nilai rata-rata masing-masing variabel, serta standar deviasi dari masing-masing variabel juga ditampilkan pada tabel 2.

\section{Uji Asumsi Klasik}

1. Uji Normalitas.

Tabel 3

Hasil Uji Normalitas

\begin{tabular}{ccc}
\hline \hline & Standardized Residual & Keterangan \\
\hline \hline Kolmogorov-Smirnov Z & 1,095 & Data terdistribusi \\
Asymp. Sig. (2-tailed) & 0,182 & normal \\
\hline \hline
\end{tabular}

Sumber: Data Diolah

Pada tabel 3 diatas dengan uji One-Sample Kolmogorov-Smirnov Test hasil dari uji tersebut menunjukan asymp. sig standardized residual adalah 0,182. Hal ini dapat disimpulkan bahwa nilai signifikannya lebih besar dari alpha 0.05 dengan demikian menunjukan data terdistribusi secara nornal. 
2. Uji Multikolinearitas

Tabel 4

Hasil Uji Multikoliniearitas

\begin{tabular}{ccccc}
\hline \hline No & Variabel & Tolerance & VIF & Keterangan \\
\hline \hline 1 & Free Cash Flow $(\mathrm{X} 1)$ & 0.807 & 1.239 & Tidak terjadi Multikolinearitas \\
2 & Profitabilitas $(\mathrm{X} 2)$ & 0.807 & 1.239 & Tidak terjadi Multikolinearitas \\
\hline \hline
\end{tabular}

Sumber: Data Diolah

Berdasarkan Tabel 3 dapat disimpulkan bahwa model regresi tersebut terbebas dari multikolinearitas. Hal ini terbukti dengan di nilai tolerance yang diperoleh untuk semua variabel independen besar dari 0,10 dan nilai VIF(variance inflation factor) dibawah 10. Dimana varibael Free cash flow menunjukan bahwa nilai tolerance sebesar 0,807> 0,10 dan nilai VIF sebesar $1,239<10$ dan Profitabilitas menunjukan bahwa nilai tolerance sebesar 0,807 $>0.10$ dan nilai VIF sebesar $1,239<10$.

3. Uji Heteroskedastisitas

Tabel 5

Hasil Uji Heteroskedastisitas

\begin{tabular}{ccccc}
\hline \hline No & Variabel & Alpha & Asymp.Sig & Keterangan \\
\hline \hline 1 & Free Cash Flow $(X 1)$ & 0,05 & 1,000 & Tidak terjadi \\
& & & & Heteroskedastisitas \\
2 & Profitabilitas $(X 2)$ & 0,05 & 1,000 & Tidak terjadi \\
& & & & Heteroskedastisitas \\
\hline
\end{tabular}

\section{Sumber: Data Diolah}

Berdasarkan hasil uji heteroskedastisitas dapat dilihat pada tabel 4 diatas menunjukan bahwa nilai Asymp. Sig pada semua variabel bebas (independen) menunjukan lebih besar dari alpha 0,05 sehingga dapat disimpulkan bahwa semua variabel independen pada penilitian ini tidak terjadi heteroskedastisitas.

\section{Analisis regresi linear dengan variabel moderating}

Analisis regresi linear dengan variabel moderating ini, digunakan untuk melihat hubungan antara sebuah variabel dependen (tidak bebas) dengan dua atau lebih variabel independen (bebas) pada tahap I (satu). Sedangkan pada tahap II (dua), analisis linear dengan variabel moderating digunakan dalam melihat pengaruh moderasi dalam mempengaruhi hubungan antara variabel independen terhadap variabel dependen. 
Tabel 6

Analisis regresi linear dengan variabel moderating Tahap I Coefficients $^{\mathrm{a}}$

\begin{tabular}{|c|c|c|c|c|c|}
\hline \multirow[b]{2}{*}{ Model } & \multicolumn{2}{|c|}{ Unstandardized Coefficients } & $\begin{array}{l}\text { Standardized } \\
\text { Coefficients }\end{array}$ & \multirow[b]{2}{*}{$\mathrm{T}$} & \multirow[b]{2}{*}{ Sig. } \\
\hline & B & Std. Error & Beta & & \\
\hline (Constant) & .815 & .177 & & 4.610 & .000 \\
\hline Free Cash Flow (X1) & 2.637 & .000 & .289 & 2.461 & .018 \\
\hline Profitabilitas (X2) & -7.347 & 1.063 & -.810 & -6.912 & .000 \\
\hline
\end{tabular}

Sumber: Data SPSS

Berdasarkan hasil analisis regresi linear tahap I diperoleh, nilai Koefisien regresi Free cash flow yaitu 2,637 dengan parameter positif yang mana dapat disimpulkan bahwa setiap peningkatan satu-satuan Free cash flow maka akan mengakibatkan kenaikan nilai koefisien Leverage sebesar 2,637.Nilai Koefisien regresi Profitabilitas yaitu $-7,347$ dengan parameter negatif yang mana dapat disimpulkan bahwa setiap peningkatan satu-satuan Profitabilitas maka akan mengakibatkan penurunan nilai koefisien Leverage sebesar -7,347

Analisis regresi tahap ke 2 (dua) adalah analisis regresi yang digunakan untuk menganalisa pengaruh moderasi. Dalam penelitian ini analisis regresi tahap ke 2 digunakan untuk menganalisa pengaruh moderasi Investment Opportunity Set terhadap hubungan Free Cash Flow dan profitabilitas dengan leverage perusahaan. Adapun teknik yang digunakan dalam analisis regresi bertingkat yaitu teknik Moderating Regression Analysis atau MRA

\section{Tabel 7}

Analisis regresi linear dengan variabel moderating Tahap II Coefficients $^{\mathrm{a}}$

\begin{tabular}{|c|c|c|c|c|c|}
\hline \multirow[b]{2}{*}{ Model } & \multicolumn{2}{|c|}{$\begin{array}{l}\text { Unstandardized } \\
\text { Coefficients }\end{array}$} & \multirow{2}{*}{$\begin{array}{c}\text { Standardized } \\
\text { Coefficients }\end{array}$} & \multirow[b]{2}{*}{$\mathrm{T}$} & \multirow[b]{2}{*}{ Sig. } \\
\hline & $\mathrm{B}$ & Std. Error & & & \\
\hline (Constant) & .689 & .163 & & 4.214 & .000 \\
\hline Free Cash Flow (X1) & 5.692 & .000 & .623 & 2.699 & .010 \\
\hline Profitabilitas (X2) & -9.150 & 1.001 & -1.009 & -9.140 & .000 \\
\hline Interaksi IOS*FCF & -9.183 & .000 & -8.652 & -1.990 & .053 \\
\hline Interaksi IOS*Profitabilitas & .856 & .411 & 8.903 & 2.080 & .044 \\
\hline
\end{tabular}

a. Dependent Variable: Leverage $(Y)$

\section{Sumber: Data SPSS}

Berdasarkan hasil analisis data, diperoleh persamaan sebagai berikut: $\mathrm{Y}=\mathrm{a}+\beta_{1} \mathrm{X}_{1}+\beta_{2} \mathrm{x}_{2}+\beta_{1} \mathrm{X}_{1} * \mathrm{Z}+\beta_{2} \mathrm{X}_{2} * \mathrm{Z}$ $\mathrm{Y}=0,689+5,692 \mathrm{X}_{1}-9,150 \mathrm{X}_{2}-9,183 \mathrm{X}_{1} * \mathrm{Z}+0,856 \mathrm{X}_{2} * \mathrm{Z}$

Dari persamaan variabel moderasi diketahui nilai t hitung interaksi antara Free Cash Flow dengan Investment Opportunity Set sebesar -1,990 dengan nilai signifikansi besar dari 0,05 yaitu 0,053. Dapat disimpulkan bahwa variabel Investment Opportunity Set tidak mempengaruhi hubungan antara Free Cash 
Flow $\left(\mathrm{X}_{1}\right)$ dengan leverage perusahaan. Dan diketahui nilai t hitung interaksi antara Profitabilitas dengan Investment Opportunity Set sebesar 2,080 dengan nilai signifikansi kecil dari 0,05 yaitu 0,044 Dapat disimpulkan bahwa variabel Investment Opportunity Set berpengaruh memperkuat dan signifikan terhadap pengaruh Profitabilitas dengan variabel Leverage.

\section{Uji f (Uji Simultan)}

Tabel 8

Uji F

ANOVA $^{\text {b }}$

\begin{tabular}{cccccc}
\hline \hline Model & Sum of Squares & Df & Mean Square & F & Sig. \\
\hline \hline Regression & 51.327 & 2 & 25.664 & 24.095 & $.000^{\mathrm{a}}$ \\
Residual & 44.734 & 42 & 1.065 & & \\
Total & 96.062 & 44 & & & \\
\hline \hline
\end{tabular}

Sumber: Data SPSS

Berdasarkan tabel 7 diatas, besarnya $F$ hitung yang diperoleh 24,095 dengan nilai signifikansi yang digunakan adalah $\alpha=0,05$ maka dapat disimpulkan bahwa model yang dijadikan dalam penelitian ini layak.

Uji t (Parsial)

Tabel 9

Hasil Uji Statistik t

Analisi Regresi Linear Tahap I dan Tahap II

\begin{tabular}{lcccc}
\hline \multirow{2}{*}{ Variabel } & \multicolumn{2}{c}{ Tahap I } & \multicolumn{2}{c}{ Tahap II } \\
\cline { 2 - 5 } & T & Sig. & t & Sig \\
\hline \hline (Constant) & 4,610 & 0,000 & 4,214 & 0,000 \\
Free Cash Flow $\left(\mathrm{X}_{1}\right)$ & 2,461 & 0,018 & 2,699 & 0,10 \\
Profitabilitas $\left(\mathrm{X}_{2)}\right.$ & $-6,912$ & 0,00 & $-9,140$ & 0,000 \\
Interaksi IOS*FCF & & & $-1,990$ & 0,053 \\
Interaksi IOS*Profitabilitas & & & 2,080 & 0,044 \\
\hline \hline
\end{tabular}

Sumber: Data Diolah

Adapun hasil dari pengujian statistik t (uji t) pada penilitian ini adalah sebagai berikut :

1. Uji t pada variabel Free Cash Flow $\left(\mathrm{X}_{1}\right)$ diperoleh $\mathrm{t}_{\text {hitung }}>\mathrm{t}$ tabel yaitu nilai $\mathrm{t}$ hitung sebesar 2,461 > 2.01669 dengan nilai signifikan 0,018 yaitu kecil dari taraf signifikan 0,05 (5\%). Hal ini menunjukan bahwa variabel Free Cash Flow $\left(\mathrm{X}_{1}\right)$ berpengaruh positif dan signifikan terhadap Leverage $(\mathrm{Y})$. Hasil uji $\mathrm{t}$ ini berarti mendukung hipotesis $1\left(\mathrm{H}_{1}\right)$.

2. Uji t pada variabel Profitabilitas $\left(\mathrm{X}_{2}\right) \mathrm{t}$ hitung $>\mathrm{t}$ tabel yaitu nilai t hitung sebesar $-6.912<2.0166$ dengan nilai signifikan 0,000 yaitu kecil dari taraf signifikan 0,05 (5\%). Hal ini menunjukan bahwa variabel Profitabilitas (X2) berpengaruh negatif dan signifikan terhadap variabel Leverage(Y). Hasil uji t ini berarti mendukung hipotesis $2\left(\mathrm{H}_{2}\right)$. 
3. Variabel moderating dalam penelitian ini ialah Investment Opportunity Set $(Z)$ diperoleh $\mathrm{t}_{\text {hitung }}>\mathrm{t}$ tabel pada interaksi Investment Opportunity Set ( $Z$ ) dengan Free Cash Flow (X1) yaitu sebesar -1,990 < 2.0166 dengan nilai signifikan 0,053 yaitu besar dari taraf signifikan 0,05 (5\%). Hal ini menunjukan bahwa variabel Investment Opportunity Set $(Z)$ tidak berpengaruh terhadap pengaruh Free Cash Flow (X1) dengan variabel Leverage (Y). Hasil uji t ini berarti mendukung hipotesis $3\left(\mathrm{H}_{3}\right)$.

4. Variabel moderating dalam penelitian ini ialah Investment Opportunity Set $(Z)$ diperoleh $\mathrm{t}_{\text {hitung }}>\mathrm{t}$ tabel pada interaksi Investment Opportunity Set $(Z)$ dengan Profitabilitas (X2) sebesar $2.080>2.0166$ dengan nilai signifikan 0,044 yaitu kecil dari taraf signifikan $0,05(5 \%)$. Hal ini menunjukan bahwa variabel Investment Opportunity Set $(Z)$ berpengaruh memperkuat dan signifikan terhadap pengaruh dengan Profitabilitas (X2) dengan variabel Leverage (Y). Hasil uji t ini berarti mendukung hipotesis $4\left(\mathrm{H}_{4}\right)$.

\section{Uji $\mathbf{R}^{2}$ (Koefisien Determinasi)}

Tabel 10

$\mathbf{U j i} \mathbf{R}^{2}$

Model Summary

\begin{tabular}{lcccr}
\hline \hline Model & $\mathrm{R}$ & R Square & Adjusted R Square & Std. Error of the Estimate \\
\hline \hline 1 & $.731^{\mathrm{a}}$ & .534 & .512 & 1.03204 \\
\hline \hline a. Predictors: (Constant), Profitabilitas (X2), Free Cash Flow (X1)
\end{tabular}

Sumber: Data SPSS

Berdasarkan hasil dari uji koefisien determinasi dimana dapat dilihat pada nilai Adjusted R Square sebesar 0,512. Hal ini menunjukan variabilitas variabel dependen dijelaskan oleh variabel independen sebesar 51,2\% atau dapat diartikan bahwa 51,2\% tingkat Leverage dipengaruhi oleh Free cash flow $\left(\mathrm{X}_{1}\right)$, dan Profitabilitas $\left(\mathrm{X}_{2}\right)$, sedangkan sisanya sebesar $48,8 \%$ dipengaruhi oleh variabel lain, yang tidak diteliti pada penelitian ini seperti, Kepemilikan Manajerial, Kepemilikan Institusional, Dividen dan Pertumbuhan Perusahaan.

\section{PEMBAHASAN}

Berdasarkan pada pengujian hipotesis yang telah dilakukan dengan melakukan pengujian terhadap persamaan regresi tentang pengaruh tentang Free Cash Flow dan Profitabilitas terhadap Leverage, serta pengaruh Investment Opportunity Set dalam memoderasi pengaruh Free Cash Flow dan Profitabilitas terhadap Leverage. Maka hasil tersebut dapat diperoleh sebagai berikut :

1. Pengaruh Free Cash Flow terhadap Leverage

Hasil pengujian hipotesis yang telah dilakukan pada hipotesis 1 menunjukan bahwa variabel Free Cash Flow berpengaruh terhadap Leverage, yang mana dapat diketahui nilai signifikansi yang diperoleh 0,018 yaitu kecil dari taraf signifikan 0,05 (5\%). Hal tersebut dapat disimpulkan bahwa Free Cash Flow berpengaruh positif dan signifikan terhadap Leverage. Seperti kutipan yang dikemukakan oleh Junaidi(2012) dalam (Zuhria, 2016) bahwa semakin besar free cash flow, akan mengakibatkan turunnya kebijakan hutang perusahaan, dimana dapat disimpulkan bahwa adanya pengaruh free cash flow terhadap Leverage. 
Hasil penelitian ini sesuai dengan penelitian yang telah dilakukan oleh (Indahningrum \& Handayani, 2009) yang meneliti tentang perusahaan Pengaruh Kepemilikan Manajerial, Kepemilikan Institusional, Dividen, Pertumbuhan Perusahaan, Free Cash Flow dan Profitabilitas terhadap Kebijakan Hutang Perusahaan manufaktur dan perusahaan non manufaktur, kecuali perusahaan keuangan aktif tercatat di BEI yang mana hasil penelitiannya menunjukan bahwa Free Cash Flow berpengaruh positif dan signifikan terhadap Leverage. Hasil penelitian ini juga sesuai dengan penelitian yang dilakukan oleh (Nurwahyudi, 2004) yang meneliti tentang pengaruh Free Cash Flow terhadap Hutang, dimana hasil penelitiannya menunjukan bahwa free Cash Flow berpengaruh terhadap hutang.

2. Pengaruh Profitabilitas terhadap Leverage

Hasil pengujian hipotesis yang telah dilakukan pada hipotesis 2 menunjukan bahwa variabel Profitabilitas berpengaruh terhadap Leverage, yang mana dapat diketahui nilai signifikansi yang diperoleh 0,000 yaitu sama dengan dari taraf signifikan 0,05 (5\%). Hal tersebut dapat disimpulkan bahwa Profitabilitas berpengaruh negatif dan signifikan terhadap Leverage.

Menurut Kutipan yang dikemukan oleh Anggria (2006) dalam (Kennedy, 2009) menyimpulkan jika profitabilitas meningkat maka proporsi penggunaan utang (leverage) akan menurun, dimana dapat disimpulkan bahwa adanya pengaruh profitabilitas terhadap Leverage.Hasil penelitian ini sesuai dengan penelitian yang telah dilakukan oleh (Suastawan, 2014) yang meneliti tentang Pengaruh arus kas bebas dan profitabilitas pada kebijakan utang pada perusahaan real estate, yang mana hasil penelitiannya menunjukan bahwa Profitabilitas berpengaruh signifikan terhadap Leverage. Hasil penelitian ini juga sesuai dengan penelitian yang dilakukan oleh (Nabela, 2012) yang meneliti tentang Pengaruh Kepemilikan Institusional, Kebijakan Dividen dan Profitabilitas Terhadap Kebijakan Hutang Pada Perusahaan Properti dan Real Estate Di Bursa Efek Indonesia, dimana hasil penelitiannya menunjukan bahwa Profitabilitas berpengaruh terhadap kebijakan hutang.

3. Pengaruh Free Cash Flow terhadap Leverage dengan Investment Opportunity Set sebagai Pemoderasi

Hasil pengujian hipotesis yang telah dilakukan pada hipotesis 3 menunjukan bahwa variabel Investment Opportunity Set tidak berpengaruh terhadap hubungan Free Cash Flow dengan variabel Leverage yang mana dapat diketahui nilai signifikansi yang diperoleh dari interaksi Investment Opportunity Set dengan Free Cash Flow sebesar 0,053 yaitu besar dari taraf signifikan 0,05 (5\%). Hal tersebut dapat disimpulkan bahwa Investment Opportunity Set tidak berpengaruh terhadap pengaruh terhadap Free Cash Flow dengan variabel Leverage.

Jensen (1986) dalam (Kennedy, 2009) menyatakan hutang dapat mengurangi keleluasaan manajemen menggunakan free cash flow bagi kegiatan dimana bersifat non maximize value. Dengan adanya utang menyebabkan manajer harus membayar pokok dan bunga pinjaman secara periodik dan harus mematuhi ketentuan-ketentuan dalam perjanjian hutang. Jensen juga menyatakan kecenderungan manajer melakukan pemborosan pada aliran kas bebas lebih besar terjadi pada perusahaan yang investment opportunity set rendah. Maka dari itu, 
pengawasan lebih dibutuhkan terhadap perusahaan yang terdapat tingkat free cash flow tinggi dengan investment opportunity set rendah. Hasil penelitian ini sesuai dengan hasil penelitian yang telah dilakukan oleh (Masruroh, 2011) yang meneliti tentang Analisis Pengaruh Moderating Investment Opportunity Set dengan Kebijakan Dividend serta Moderating Investment Opportunity Set dengan Arus Kas Bebas terhadap Tingkat Leverage Perusahaan Makanan dan Minuman yang Terdaftar Di BEI, yang mana hasil penelitiannya menunjukan bahwa Investment Opportunity Set tidak mempengaruhi hubungan antara Free Cash Flow dengan variabel Leverage. Hasil penelitian ini juga sesuai dengan penelitian yang dilakukan oleh (Kennedy, 2009) yang meneliti tentang Pengaruh Dividen, Aliran Kas Bebas, Ukuran Perusahaan, Profitabilitas dan Risiko terhadap Leverage Perusahaan dengan Set Kesempatan Investasi (IOS) Sebagai Variabel Moderating pada Perusahaan Manufaktur yang Listing di Bursa Efek, dimana hasil penelitiannya menunjukan bahwa Investment Opportunity Set tidak berpengaruh terhadap pengaruh terhadap Free Cash Flow dengan variabel Leverage

4. Pengaruh Profitabilitas terhadap Leverage dengan Investment Opportunity Set sebagai Pemoderasi

Hasil pengujian hipotesis yang telah dilakukan pada hipotesis 4 menunjukan bahwa variabel Investment Opportunity Set berpengaruh memperkuat dan signifikan terhadap pengaruh Profitabilitas dengan variabel Leverage yang mana dapat diketahui nilai signifikansi yang diperoleh dar interaksi Investment Opportunity Set dengan Profitabilitas sebesar 0,044 yaitu kecil dari taraf signifikan 0,05 (5\%). Hal tersebut dapat disimpulkan bahwa Investment Opportunity Set berpengaruh memperkuat dan signifikan terhadap pengaruh Profitabilitas dengan variabel Leverage

Ismiyanti \& Hanafi, (2004) juga menyatakan terdapat hubungan negatif antara profitabilitas dengan utang. Sesuai dengan Teori pecking order, jika semakin tinggi profitabilitas perusahaan mengakibatkan semakin besar juga tersedianya suatu dana internal digunakan investasi, sehingga penggunaan hutang lebih rendah. Rofniati. Hasil penelitian ini sesuai dengan hasil penelitian yang telah dilakukan oleh (Kennedy, 2009) yang meneliti tentang Pengaruh Dividen, Aliran Kas Bebas, Ukuran Perusahaan, Profitabilitas dan Risiko terhadap Leverage Perusahaan dengan Set Kesempatan Investasi (IOS) Sebagai Variabel Moderating pada Perusahaan Manufaktur yang Listing di Bursa Efek, dimana hasil penelitiannya menunjukan bahwa Investment Opportunity Set mempengaruhi hubungan antara Profitabilitas dengan variabel Leverage. Namun berbeda dengan hasil penelitian yang dilakukan oleh (Rahayu \& Wirawan Yasa, 2018), yang meneliti tentang Investment Opportunity Set (IOS) Sebagai Sebagai Pemoderasi Pengaruh Profitabilitas dan Kepemilikan Manajerial Terhadap Kebijkan Hutang, dimana hasil penelitiannya menunjukan bahwa Investment Opportunity Set tidak mampu memperkuat pengaruh negative profitabilitas terhadap kebijakan hutang. Dengan kata lain bahwa Opportunity Set tidak mempengaruhi hubungan antara Profitabilitas dengan variabel Leverage 


\section{SIMPULAN}

Dari hasil pengujian hipotesis yang telah dilakukan mengenai analisis Pengaruh Free Cash Flow dan Profitabilitas terhadap Leverage dengan Investment Opportunity Set Sebagai Variabel Moderating maka dapat ditarik kesimpulan sebagai berikut:

1. Variabel Free Cash Flow berpengaruh positif dan signifikan terhadap Leverage dengan nilai sig $0,018<0,05$, maka hipotesis diterima karna mendukung hipotesis $1\left(\mathrm{H}_{1}\right)$ bahwa Free Cash Flow berpengaruh positif dan signifikan terhadap Leverage.

2. Variabel Profitabilitas mempengaruhi leverage secara negatif dan signifikan dengan nilai sig $0,000<0,05$, maka hipotesis diterima karna mendukung hipotesis $2\left(\mathrm{H}_{2}\right)$ bahwa Profitabilitas berpengaruh negatif dan signifikan terhadap Leverage.

3. Variabel Investment Opportunity Set tidak mempengaruhi terhadap hubungan Free cash flow dengan variabel Leverage dengan nilai sig 0,053>0,05, maka hipotesis diterima karena mendukung hipotesis $3\left(\mathrm{H}_{3}\right)$ bahwa Investment Opportunity Set tidak berpengaruh terhadap hubungan antara free cash flow dengan Leverage.

4. Variabel Investment Opportunity Set berpengaruh memperkuat dan signifikan pada hubungan antara profitabilitas dengan variabel Leveragee dengan nilai sig $0,044<0,05$, maka hipotesis diterima karena mendukung hipotesis $4\left(\mathrm{H}_{4}\right)$ bahwa Investment Opportunity Set berpengaruh terhadap hubungan antara Profitabilitas dengan Leverage.

\section{UCAPAN TERIMAKASIH}

Selesainya penelitian ini penulis banyak mendapatkan bantuan dan dorongan baik secara moril, maupun spritual, oleh karena itu penulis ingin menyampaikan rasa terimakaih yangsebesar besarnya kepada Bapak Febryandhie Ananda, SE.,M.Si selaku ketua STIE "KBP" Padang, Ibu Fabsri Susanti selaku ketua program studi Manajemen. Ibu Aminar Sutra Dewi, SE.,M.Si selaku pembimbing yang telah bersedia meluangkan waktu membimbing dalam penulisan penelitian ini dengan penuh perhatian, memberikan arahan serta masukan dalam penyelasaian penelitian ini sehingga penulis mampu untuk menyelesaikan penelitian ini dengan baik. Ibu Maria Magdalena selaku penasehat akademik program studi manajemen. Serta semua pihak yang telah banyak membantu penulis yang tidak bisa penulis sebutkan satu persatu.

\section{DAFTAR PUSTAKA}

Afriyeni, A., \& Marlius, D. (2017). Analisis Pengaruh Harga Saham Perdana Terhadap Abnormal Return Yang Diterima Investor Studi Pada Bursa Efek Indonesia. https://doi.org/10.31219/osf.io/8z7hx

Afriyeni, A., \& Marlius, D. (2018). Analisis Pengaruh Informasi Prospektus Perusahaan Terhadap Initial Return Saham Pada Pasar Perdana Di Bursa Efek Indonesia. https://doi.org/10.31219/osf.io/kt6c4 
Afriyeni, A., \& Marlius, D. (2019). Analisis Faktor-Faktor Yang Berpengaruh Terhadap Ketepatan Waktu Penyampaian Laporan Keuangan Pada Perusahaan Yang Listing Di Bursa Efek Indonesia. https://doi.org/10.31219/osf.io/rv4qf

Afriyeni, A., \& Marlius, D. (2019). Analisis Tingkat Pengembalian Dan Risiko Investasi (Studi Pada Industri Manufaktur Yang Terdaftar Di Bursa Efek Indonesia). https://doi.org/10.31219/osf.io/cfb92

Afriyeni, A., \& Fernos, J. (2019). Analisis Pengaruh Faktor Determinan Terhadap Economic Value Added Dan Implikasinya Terhadap Pergerakan Harga Saham Properti Di Bursa Efek Indonesia. https://doi.org/10.31219/osf.io/qf5nm

Brigham, \& Houston. (2010). dasar - dasar manajemen keuangan (11th ed.). jakarta: salemba Empat.

Dewi, A. S. (2012). Pengaruh Corporate Governance dan Leverage Terhadap Kinerja Keuangan Pada Perbankan yang Terdaftar di BEI. Kajian Akuntansi Dan Auditing, 7(1).

Fitriyah, F. K., \& Hidayat, D. (2006). Pengaruh Kepemilikan Institusional, Set Kesempatan Investasi Dan Arus Kas Bebas Terhadap Hutang. Media Riset Akuntansi, 1(1), 31-76.

Ghozali, imam. (2012). Aplikasi analisis multivariate dengan program IBM SPSS (1st ed.). Undip.

Gunawan, K., Darmawan, A. S., \& Purnamawati, I. G. A. (2015). Leverage Terhadap Manajemen Laba Pada Perusahaan Manufaktur Yang Terdaftar Di Bursa Efek Indonesia ( BEI ). E-Journal S1 Ak Universitas Pendidikan Ganesha, 3(1).

Hardiningsih, P., \& Oktaviani, R. M. (2012). Determinan kebijakan hutang (dalam agency theory dan pecking order theory). Dinamika Akuntansi, Keuangan Dan Perbankan Universitas Stikubank, 1(1), 11-24.

Indahningrum, R. P., \& Handayani, R. (2009). Pengaruh Kepemilikan Manajerial,Kepemilikan Institusional, Dividen, Pertumbuhan Perusahaan,Free Cash Flow dan Profitabilitas terhadap Kebijakan Hutang Perusahaan. Jurnal Bisnis Dan Akuntansi, 11(3), 189-207.

Kennedy, Fitrios, R., \& Fitra, R. (2009). Pengaruh Dividen, Aliran Kas Bebas, Ukuran Perusahaan, Profitabilitas Dan Risiko Terhadap Leverage Perusahaan Dengan Set Kesempatan Investasi (IOS) Sebagai Variabel Moderating (Suatu 
Studi Empiris Terhadap Perusahaan Manufaktur yang Listing di Bursa Efek . Jurnal Kajian Akuntansi Dan Auditing, 4(1), 66-77.

Liputan6. (2017). No Title. Retrieved from isnis.liputan6.com/read/3040594/ekonom-sebut-daya-beli-masyarakat-turunini-sebabnya? source=search

Masruroh, Desi Nursanti, T., \& Lisa. (2011). Analisis Pengaruh Moderating Investment Opportunity Set Dengan Kebijakan Dividend Serta Moderating Investment Opportunity Set Dengan Arus Kas Bebas Terhadap Tingkat Leverage Perusahaan Makanan Dan Minuman Yang Terdaftar Di Bei Periode 2003-2007. Journal the Winners, 12(2), 121-141.

Masruroh, Nursanti, T. D., \& Lisa. (2007). Analisis Pengaruh Moderating Investment Opportunity Set Dengan Kebijakan Dividend Serta Moderating Investment Opportunity Set Dengan Arus Kas Bebas Terhadap Tingkat Leverage Perusahaan Makanan Dan Minuman Yang Terdaftar Di BEI Periode 2003-2007. Journal T He WINNERS, 12(2), 121-141.

Nabela, Y. (2012). Pengaruh kepemilikan institusional, kebijakan dividen dan profitabilitas terhadap kebijakan hutang pada perusahaan properti dan real estate di bursa efek indonesia. Jurnal Manajemen, 1(8), 1-8.

NATALIA, D. (2013). Pengaruh Profitabilitas Dan Kesempatan Investasi Terhadap Kebijakan Dividen Pada Perusahaan Manufaktur Yang Terdaftar Di Bei. Jurnal Akuntansi, 1(1).

Novelma, S. (2014). Pengaruh Insider Ownership, Free Cash Flow dan Kebijakan Dividen (Pada Perusahaan Manufaktur yang Terdaftar di BEI). Jurnal Akuntansi, 2(1), 1-27.

Nurwahyudi, H. (2004). Pengaruh Free Cash Flow terhadap Hutang. Media Riset Akuntansi, Auditing Dan Informasi, 4(4).

Rahayu, P., \& Wirawan Yasa, G. (2018). Investment Opportunity Set (IOS) Sebagai Pemoderasi Pengaruh Profitabilitas Dan Kepemilikan Manajerial Terhadap Kebijakan Utang. E-Jurnal Akuntansi Universitas Udayana, 22, 856-883.

Sari, D. P., \& Dewi, A. S. (2018). Pengaruh Likuiditas Dan Solvabilitas Terhadap Profitabilitas Pada Perusahaan Makanan Dan Minuman Yang Terdaftar Di Bursa Efek Indonesia Periode 2013-2015. https://doi.org/10.31219/osf.io/n75gr

Suastawan, I. P. (2014). Pengaruh arus kas bebas dan profitabilitas pada kebijakan utang perusahaan real estate. E-Jurnal Akuntansi, 3(1), 684-694. 
Sudarmadji, Ardi Murdoko Sularto, L. (2007). Pengaruh Ukuran Perusahaan, Profitabilitas Leverage, dan Tipe Kepemilikan Perusahaan Terhadap Luas Voluntary Disclosure Laporan Keuangan Tahunan. Proceeding PESAT Gunadarma, 2(21-22), 53-61.

Sugiyono. (2015). Statistik Nonparameteris untuk Penelitian. Bandung: ALFABETA. 